\title{
Overexpression of P-glycoprotein, MRP2, and CYP3A4 impairs intestinal absorption of octreotide in rats with portal hypertension
}

\author{
Xiaoyu Sun', Shunxiong Tang ${ }^{2 \dagger}$, Binbin Hou ${ }^{3 \dagger}$, Zhijun Duan ${ }^{1 *}$ (D), Zhen Liu', Yang Li ${ }^{4,5}$, Shoucheng He', \\ Qiuming Wang ${ }^{1}$ and Qingyong Chang ${ }^{6^{*}}$
}

\begin{abstract}
Background: Portal hypertension (PH) is the main cause of complications and death in liver cirrhosis. The effect of oral administration of octreotide $(\mathrm{OCT})$, a drug that reduces $\mathrm{PH}$ by the constriction of mesenteric arteries, is limited by a remarkable intestinal first-pass elimination.

Methods: The bile duct ligation (BDL) was used in rats to induce liver cirrhosis with $\mathrm{PH}$ to examine the kinetics and molecular factors such as P-glycoprotein (P-gp), multidrug resistance-associated protein 2 (MRP2) and cytochrome P450 3A4 (CYP3A4) influencing the intestinal OCT absorption via in situ and in vitro experiments on jejunal segments, transportation experiments on Caco-2 cells and experiments using intestinal microsomes and recombinant human CYP3A4. Moreover, RT-PCR, western blot, and immunohistochemistry were performed.

Results: Both in situ and in vitro experiments in jejunal segments showed that intestinal OCT absorption in both control and PH rats was largely controlled by P-gp and, to a lesser extent, by MRP2. OCT transport mediated by P-gp and MRP2 was demonstrated on Caco-2 cells. The results of RT-PCR, western blot, and immunohistochemistry suggested that impaired OCT absorption in PH was in part due to the jejunal upregulation of these two transporters. The use of intestinal microsomes and recombinant human CYP3A4 revealed that CYP3A4 metabolized OCT, and its upregulation in PH likely contributed to impaired drug absorption.
\end{abstract}

Conclusions: Inhibition of P-gp, MRP2, and CYP3A4 might represent a valid option for decreasing intestinal first-pass effects on orally administered OCT, thereby increasing its bioavailability to alleviate $\mathrm{PH}$ in patients with cirrhosis.

Keywords: P-glycoprotein, Multidrug resistance-associated protein 2, Cytochrome P450 3A4, Octreotide, Intestinal absorption, Portal hypertension

\section{Background}

Portal hypertension $(\mathrm{PH})$ is defined by a portal vein pressure greater than $10 \mathrm{mmHg}$ and is the main cause of complications and death in patients with liver cirrhosis.

\footnotetext{
*Correspondence: cathydoctor@sina.com; qychang0409@163.com ${ }^{\dagger} \mathrm{Co}$-first author: Shunxiong Tang and Binbin Hou

1 Department of Gastroenterology, First Affiliated Hospital of Dalian Medical University, Dalian 0086-116011, China

${ }^{6}$ Department of Neurosurgery, Affiliated Zhongshan Hospital of Dalian

University, Dalian, China

Full list of author information is available at the end of the article
}

So far, standard treatments against $\mathrm{PH}$ are mainly aimed at treating varicosis and variceal bleeding. The treatment stratification is based on the action on different clinical $\mathrm{PH}$ stages. The purpose of this treatment in $\mathrm{PH}$ patients with cirrhosis without varicose veins is to prevent both varicosis (pre-primary prophylaxis), and variceal bleeding in patients with gastroesophageal varices (primary prophylaxis). Under the condition of acute variceal bleeding (AVB), the treatment consists of hemostasis and prevention of early re-bleeding, and it should prevent delayed re-bleeding in AVB survivors (secondary 
prophylaxis) [1]. Early control of $\mathrm{PH}$ is recommended in clinical practice; however, side effects and poor efficacy of current oral medicines limit the success of $\mathrm{PH}$ therapy. Non-selective beta-blockers (NBSS) are recommended as a standard therapy in the primary and secondary prophylaxis against variceal bleeding in patients with cirrhosis and high risk esophageal varices (EVs) [2]. Although several studies evaluated the efficacy of NBSS in the inhibition of the development or aggravation of varices, results are controversial; no recommendation is available for patients with cirrhosis without varices or with low risk of small varices [1]. NBSS reduce the probability of bleeding from $40 \%-50 \%$ (without any therapy) to $25 \%$ over a 2 -year period, but the efficiency is decreasing with time. Moreover, not all patients exhibit a hemodynamic response, and these non-responsive patients have a risk of bleeding similar to the one of non-treated patients. If the hepatic vein pressure gradient (HVPG) is not measured, clinical protocols should be used for titrating NBSS (reduction of resting heart rate to 55 beats/min or $25 \%$ of the baseline) [3]. Moreover, at least one third of the patients are unresponsive, have contraindications or cannot tolerate NBSS therapy $[4,5]$. Thus, NBSS effect can be limited by its side effects.

Hepatic and intestinal first-pass effect affects the oral absorption and bioavailability of medicines. Little is known about how $\mathrm{PH}$ and the vascular changes often associated with this condition affect drug absorption. Previous studies showed that mal-absorption or enhanced absorption of drugs can occur depending on the extent of different lesions in liver cirrhosis because of the changes in the expression or activity of drug transporters or metabolic enzymes in liver or intestine [6-16], while venous shunt formation in PH may effectively increase the absorption of various drugs [17]. Hepatic first-pass effects are reduced during $\mathrm{PH}$ due to the increased collateral circulation.

The ATP-driven drug efflux pump P-glycoprotein (P-gp, MDR1-gene product, mdrla and mdr1b subtypes) $[18,19]$ and the multidrug resistance-associated protein 2 (MRP2, mrp2-gene product) [20, 21] largely influence drug uptake, distribution, and excretion in the intestine, liver and kidney. Octreotide (OCT), an octapeptide that pharmacologically mimics natural somatostatin, can reduce portal pressure and portal blood flow by the induction of selective splanchnic vasoconstriction [22]. These effects are partly mediated by the inhibition of the release of vasoactive substances including glucagon, which indirectly causes dilatation of the splanchnic vessels $[23,24]$. OCT is widely used in the treatment of $\mathrm{PH}$ hemorrhage and related complications [24, 25]. Practice guidelines recommend OCT as an adjuvant therapy in the control of variceal hemorrhage, along with timely therapeutic endoscopy [26-28]. It is currently recommended that intravenous (i.v.) OCT should be started as soon as possible before the endoscopic therapy in suspected variceal hemorrhage [29]. OCT is as effective as terlipressin in patients with AVB [30]. In addition, OCT has few side effects, since only mild hyperglycemia and abdominal cramps have been reported. It is routinely used worldwide largely because of its excellent safety profile and ease of administration [3,31], and it is a universally recognized drug that can reduce $\mathrm{PH}$ and control variceal bleeding, being the only available vasoactive drug in the United States [31]. Therefore, OCT may be considered as an ideal oral drug to decrease PH. According to the current $\mathrm{PH}$ treatment guidelines, it is expected that in the future, oral OCT, which is the topic this work focused on, will be used in pre-primary, primary, and secondary prophylaxis of variceal bleeding, except on AVB patients. Thus, our hope was to find an effective way to prevent $\mathrm{PH}$ development with an early, continuous, and lifelong strategy such as the treatment against hypertension. However, OCT exhibits low systemic bioavailability upon ingestion due to its polypeptide structure and its use is limited to parenteral administration. After subcutaneous or i.v. injection, OCT is rapidly and completely absorbed with few side effects [32]. Additionally, patients with liver cirrhosis have prolonged elimination of OCT with a greatly increased $t_{1 / 2}$ and decreased total body clearance [33]. OCT is stable against enzymatic degradation in the stomach, meaning that it can overcome problems, to a certain extent, associated with the short biological half-life of therapeutically active peptides [34]. Thus, this drug may represent a valuable oral medicine for long-term use that can persistently decrease $\mathrm{PH}$. Previous studies recommended the oral administration of a novel OCT formulation as an alternative to parenteral OCT treatment in patients with acromegaly [35, 36]. As regard its chronic use, OCT long-acting release (LAR) can be administered once monthly by intramuscular injection [37]. Since OCT-LAR, such as lanreotide, is similar to OCT regarding pharmacology, clinical actions, and most adverse effects [38], it remains unclear whether OCT-LAR can be safely used for PH in patients with compensated cirrhosis [39]. In addition, the appropriate dose and schedule required for long-term therapy of OCT-LAR are not clear [40]. The safety profile, pharmacokinetics, and pharmacodynamics of OCT-LAR have not been carefully studied in patients with cirrhosis [39, 41]. In addition, OCT-LAR costs much more than conventional $\mathrm{OCT}$, thus resulting in a huge economic burden for patients [40]. Moreover, OCT-LAR injection should be performed at the hospital, while the hope of this work is to realize a therapy involving the oral administration of 
OCT performed at home, which is more convenient for patients.

OCT absorption across the blood-brain barrier [42] and into renal proximal tubules [21] is prevented by P-gp and MRP2. In addition, cytochrome P450 3A4 (CYP3A4, cyp3A1-gene product in rats), one of the most important CYP enzymes in the small intestine, also functions as a barrier against drugs, including polypeptides [43]. The substrates of P-gp, MRP2, and CYP3A4 often overlap, leading to synergistic effects on the same substrate. Thus, our hypothesis is that P-gp, MRP2, and CYP3A4 might contribute to the intestinal first-pass effect on OCT, thus limiting its oral absorption. Therefore, the aim of the current study was to determine whether P-gp and MRP2 affect OCT transport, and whether CYP3A4 affects OCT metabolism in the intestine of rats with cirrhosis and $\mathrm{PH}$, with the intention of improving the intestinal absorption of OCT and optimizing oral therapeutic strategies for decreasing $\mathrm{PH}$.

\section{Methods}

\section{Animal care}

Male Sprague Dawley rats (7 weeks \pm 2 days, weighing 200-220 g) were purchased from the Experimental Animal Center at Dalian Medical University (Liaoning, China). This study was carried out in strict accordance with the International Council for Laboratory Animal Science. All animal experiments were conducted in accordance with the protocols approved by the Experimental Animal Ethical Committee of Dalian Medical University (No. L20180301). All surgeries were performed under fully anesthesia with ether (Laboratory regent, $5 \mathrm{~mL}$ inhalation for 30-45 s) to obtain well anesthetized rats to allow experiments as previously reported $[44,45]$. The term "well anesthetized" is used when the corneal reflex and pain reflex in rats are disappeared. The effect of anesthesia began to fade after $20 \mathrm{~min}$, thus, the rats were anesthetized again with an additional dose of anesthetic. Animals remained anesthetized during the whole experiment. After the establishment of $\mathrm{PH}$ rat models, the rats were anesthetized every other hour for $24 \mathrm{~h}$ to reduce the postoperative pain and were kept under observation for potential abnormalities. All the necessary efforts were made to reduce the number of dropouts. All animal experiments were carried out after $\mathrm{PH}$ rats were successfully established, and no dropout was observed during anesthesia or each experiment. Each experiment was successfully finished. The successful rate of the model in our research was approximately $70 \%$. Animals were euthanized through cervical dislocation under anesthesia.

\section{Animal model}

Rats were housed at room temperature $\left(24-26{ }^{\circ} \mathrm{C}\right)$ and relative humidity of $60 \%-65 \%$ in a specific pathogen-free environment. They had free access to water and were fed with a chow diet for 3 days prior to any experiment. The animals were fasted for $12 \mathrm{~h}$ with water available ad libitum prior to the pharmacokinetic experiments. Biliary cirrhosis with $\mathrm{PH}$ was induced via bile duct ligation (BDL) as previously described [46]. The bile duct was isolated and double-ligated using 3-0 silk sutures. The abdominal wall and skin were closed using $4-0$ silk sutures, and the antibiotic gentamicin $(30 \mathrm{mg} / \mathrm{kg}, 0.3 \mathrm{~mL})$ was administered through an intramuscular injection. Rats were allowed to recover with unrestricted access to food and water for a 4-week period after surgery. In this study, 80 rats were randomly selected from a total of 100 to build the PH rat model, and 57 were successfully established. Then, 48 of them were randomly selected and divided into the respective $\mathrm{PH}$ experimental groups $(\mathrm{n}=4$ or 6$)$. The remaining $\mathrm{PH}$ rats were kept for a further potential use. Portal vein pressure was measured in $\mathrm{PH}$ rats before each experiment, resulting in an average value of $15.56 \pm 2.36 \mathrm{mmHg}$. Administration methods and measurements in each group are further specified in the appropriate sections of the text. The jejunum was the intestinal tract investigated in the present study, since it is the main site of OCT absorption [47]. Sample size in each group was determined according to research articles relevant to this study.

\section{Pharmacokinetic interaction study In situ jejunal perfusion technique}

The experimental procedure was performed as previously reported. Briefly, the mean length of the proximal jejunum (approximately $2 \mathrm{~cm}$ distal to the ligament of Treitz) was $10 \pm 1 \mathrm{~cm} \mathrm{[48].} \mathrm{An} \mathrm{oxygenated} \mathrm{Krebs-Ringer}$ bicarbonate buffer (KRB) solution ( $\mathrm{pH}$ 7.4) containing $0.5 \mathrm{mM} \mathrm{MgCl}, 4.5 \mathrm{mM} \mathrm{KCl}, 120 \mathrm{mM} \mathrm{NaCl}, 0.7 \mathrm{mM}$ $\mathrm{Na}_{2} \mathrm{HPO}_{4}, 1.5 \mathrm{mM} \mathrm{NaH} \mathrm{PO}_{4}, 1.2 \mathrm{mM} \mathrm{CaCl}, 15 \mathrm{mM}$ $\mathrm{NaHCO}_{3}$, and $10 \mathrm{mM}$ glucose was perfused at a flow rate of $0.4 \mathrm{~mL} / \mathrm{min}$ using a peristaltic pump through an inlet tube kept at $37{ }^{\circ} \mathrm{C}$. After a 30 -min equilibration period, the following drugs (dissolved in KRB) were administered: (1) $10 \mu \mathrm{M}$ OCT (99\% purity, Chengdu Xinlinbang Bio-pharmaceutical Co.) (Group A, control group, $\mathrm{n}=4$ ); (2) $10 \mu \mathrm{M}$ OCT plus $1 \mathrm{mM}$ verapamil hydrochloride (Sigma-Aldrich, St. Louis, MO) (Group B, $\mathrm{n}=4$ ); (3) $10 \mu \mathrm{M}$ OCT plus $1 \mathrm{mM}$ probenecid (Sigma-Aldrich, St. Louis, MO) (Group C, $\mathrm{n}=4$ ); and (4) $10 \mu \mathrm{M}$ OCT plus $1 \mathrm{mM}$ verapamil hydrochloride plus $1 \mathrm{mM}$ probenecid (Group D, $\mathrm{n}=4$ ). Portal vein blood $(200-300 \mu \mathrm{l})$ was collected at 5, 10, 15, 30, 45, and $60 \mathrm{~min}$ for OCT determination via LC-MS/MS. The AUC was calculated using 
the integral method. These experiments were performed both in healthy and $\mathrm{PH}$ rats; the latter was called Group A1, B1, C1, and D1 ( $n=4$ per group).

\section{In vitro everted intestinal sac preparation}

Rat jejunum $(10 \pm 1 \mathrm{~cm})$ was transected approximately $2 \mathrm{~cm}$ distal to the ligament of Treitz [48]. The empty sac was filled with $1 \mathrm{~mL} \mathrm{KRB} \mathrm{(pH} \mathrm{7.4)} \mathrm{and} \mathrm{placed} \mathrm{in} \mathrm{incu-}$ bation medium (mucosal solution) containing (1) $10 \mu \mathrm{M}$ OCT (Group A, control group); (2) $10 \mu \mathrm{M}$ OCT plus $1 \mathrm{mM}$ verapamil hydrochloride (Group B); (3) $10 \mu \mathrm{M}$ OCT plus $1 \mathrm{mM}$ probenecid (Group C); or (4) $10 \mu \mathrm{M}$ OCT plus $1 \mathrm{mM}$ verapamil hydrochloride plus $1 \mathrm{mM}$ probenecid (Group D) ( $n=4$ for each group). Samples of the lumen of the sac $(50 \mu \mathrm{l})$ were collected at $10,15,30$, $45,60,90$, and $120 \mathrm{~min}$ for OCT determination via LCMS/MS. The AUC was calculated using the trapezoid method. These experiments were performed in both control and PH rats; the latter was called Group A1, B1, C1, and D1 ( $\mathrm{n}=4$ per group).

\section{Caco-2 permeability assay Cell culture}

Caco-2 cells (purchased from the Type Culture Collection of the Chinese Academy of Sciences, Shanghai, China) at passage 30 to 33 were used in this study. Cells were routinely cultured as previously described with minor modifications [49]. Cells were seeded onto Transwell inserts in 12-well dishes at a density of $5 \times 10^{5}$ cells/well (\#3401; $0.4 \mu \mathrm{m}$ pore size, growth area of $1.13 \mathrm{~cm}^{2}$, Corning, NY, USA), and the medium was replaced with D-Hanks solution every other day except for the treatment days [50]. No sign of Caco- 2 cell death was observed at OCT concentrations of 1,10 , and $50 \mu \mathrm{M}$ as determined by the LDH-cytotoxicity assay (data not shown).

Cell monolayer integrity was evaluated through the transepithelial electrical resistance (TEER) using a Millicell ERS resistance system (Millipore, Bedford, MA, USA) at $37{ }^{\circ} \mathrm{C}$. Each TEER value was corrected for background resistance determined on an extracellular matrixcoated cell culture insert without cells. Monolayers that exhibited a TEER value $>350 \Omega \cdot \mathrm{cm}^{2}$ on the 21 st day of cell culture were used for the transport study.

\section{Transport study}

Caco-2 transport study was performed as previously described [50]. Briefly, apical to basolateral (A to B) or basolateral to apical (B to A) transport assay started after gentle removal of the HBSS buffer in the donor compartment and addition of $1.4 \mathrm{~mL}$ (1) OCT (10 $\mu \mathrm{M})$; (2) OCT $(10 \mu \mathrm{M})$ plus the specific P-gp inhibitor rhodamine 123 (1 mM; Sigma-Aldrich, St. Louis, MO); or (3) OCT
$(10 \mu \mathrm{M})$ plus probenecid $(1 \mathrm{mM})$. A to B assay was performed to determine the extent of OCT absorption, while $\mathrm{B}$ to A assay was performed to measure OCT secretion. As regard A to B assay, the apical (upper) chamber was filled with $1.6 \mathrm{~mL}$ test drug solution in HBSS, while the receiver basolateral (lower) compartment was filled with $0.6 \mathrm{~mL}$ HBSS alone. Conversely, in B to A assay the upper and lower chambers were filled with $0.6 \mathrm{~mL} \mathrm{HBSS}$ and $1.6 \mathrm{~mL}$ test drug, respectively. A small aliquot $(0.05 \mathrm{~mL})$ of HBSS was collected to determine the OCT loading concentration $\mathrm{C}_{0}$. The TEER value was determined at different incubation times to verify the integrity of the monolayer after buffer change. A total amount of $100 \mu \mathrm{L}$ was collected from the receiver compartment at $5,15,30,60$, and 90 min to determine the OCT concentration by LCMS/MS. The concentration kinetic of OCT uptake was measured at $\mathrm{pH} 6.0$ over a concentration range of 1 to $50 \mu \mathrm{M}$ at $37^{\circ} \mathrm{C}$, as described above. The apparent permeability coefficient $\left(\mathrm{P}_{\text {app }}, \mathrm{cm} / \mathrm{s}\right)$ of OCT across the Caco-2 monolayer was calculated using the following equation:

$$
\mathrm{P}_{\mathrm{app}}=\Delta \mathrm{A}_{\mathrm{R}} / \Delta t / \text { Area } \times 60 \times \mathrm{C}_{0}
$$

where $\Delta \mathrm{A}_{\mathrm{R}}$ is the amount of drug accumulated in the receiver compartment during the interval time $(\Delta t)$ and Area is the surface area of the filter/membrane of the Transwell $\left(\mathrm{cm}^{2}\right)$. The permeability direction rate (PDR) was calculated by the ratio of $\mathrm{P}_{\text {app }}$ in the $\mathrm{B}$ to $\mathrm{A}$ direction versus that in the $A$ to $B$ direction, as follows:

$$
\mathrm{PDR}=\mathrm{P}_{\text {app }}(\mathrm{B} \text { to } \mathrm{A}) / \mathrm{P}_{\text {app }}(\mathrm{A} \text { to } \mathrm{B})
$$

\section{OCT metabolism by CYP3A in rat microsomal preparation}

Microsomes from the small intestine of healthy rats and $\mathrm{PH}$ rats were obtained as previously described [51], and their protein concentration $(0.53 \pm 0.05 \mathrm{mg} / \mathrm{mL}$ and $0.52 \pm 0.06 \mathrm{mg} / \mathrm{mL}$ total protein, respectively) was measured using the BCA method (Beijing Solarbio Science \& Technology Co., Ltd). The reaction mixture $(500 \mu \mathrm{L})$ containing $0.4 \mathrm{mg}$ intestinal microsome protein, $100 \mathrm{mM}$ potassium phosphate buffer (PPB; $\mathrm{pH} 7.4$ ), a NADPHgenerating system $\left(3.3 \mathrm{mM} \mathrm{MgCl}_{2}, 1.3 \mathrm{mM} \beta\right.$-NADP ${ }^{+}$, $3.3 \mathrm{mM}$ glucose 6-phosphate, $0.4 \mathrm{U} / \mathrm{mL}$ glucose-6-phosphate dehydrogenase), and OCT (1000 ng/mL), was incubated at $37{ }^{\circ} \mathrm{C}$ for $30 \mathrm{~min}$ with or without ketoconazole (10 $\mu \mathrm{M}$, Sigma-Aldrich, St. Louis, MO). CYP3A activity was measured using a fluorescent quantitative detection kit (Genmed Scientifics Inc., U.S.A.) with the NADPH regenerating system after pre-incubation at $37{ }^{\circ} \mathrm{C}$ for 0 , 2, 10, 20 or $30 \mathrm{~min}$. In addition, the effect of OCT preincubation on CYP3A inactivation was determined by pre-incubating OCT (1000 ng/mL) with microsomes, 
prepared in $\mathrm{PPB}$, for $0,2,10,20$ or $30 \mathrm{~min}$ at $37^{\circ} \mathrm{C}$ in the presence of a NADPH regenerating system. The organic phase was evaporated to dryness and the OCT content in the residue was measured by LC-MS/MS.

Microsomes prepared from healthy rats were equally divided into 2 groups: (1) OCT (Group $\mathrm{N}+\mathrm{OCT}$ ) and (2) OCT + ketoconazole (Group $\mathrm{N}+\mathrm{OCT}+\mathrm{K}$ ). Similarly, microsomes prepared from $\mathrm{PH}$ rats were divided into two groups: (1) OCT (Group PH + OCT) and (2) $\mathrm{OCT}+$ ketoconazole (Group $\mathrm{PH}+\mathrm{OCT}+\mathrm{K})(\mathrm{n}=6$ in each group). The control group (Group OCT; $n=6$ ) contained OCT without microsomes. Each sample was tested 3 times.

\section{OCT metabolism by recombinant human cytochrome $P 450$ $3 A 4$}

All incubations were performed at $37^{\circ} \mathrm{C}$ in a water bath. Recombinant human cDNA-expressing P450 isozyme 3A4 (BD Gentest Supersomes) was carefully thawed on ice prior to each experiment. The reaction mixture (200 $\mu \mathrm{L}$ ) contained $10 \mu \mathrm{L}$ human recombinant CYP3A4, $2 \mu \mathrm{L}$ OCT (at different concentrations; see below), $168 \mu \mathrm{PPB}$ $(100 \mathrm{mM})$, and $20 \mu \mathrm{L}$ NADPH $(1 \mathrm{mM})$. After a 5 -min preincubation at $37^{\circ} \mathrm{C}$, the reaction was started by the addition of NADPH and ended 30 min later by the addition of $500 \mu \mathrm{L}$ methanol. Control samples without NADPH and samples without OCT were also included. At the end of each reaction, samples were centrifuged at $12,000 \mathrm{~g}$ for $5 \mathrm{~min}$ at $4{ }^{\circ} \mathrm{C}$ to precipitate the proteins, and the supernatant was subjected to LC-MS/MS analysis to determine the OCT content. Each sample was tested 4 times. CYP3A4 activity with and without OCT incubation was assessed using a fluorescent quantitative detection kit.

To determine the optimal experimental conditions, different incubation times such as 5, 10, 15, 20, and $30 \mathrm{~min}$ were used together with a CYP3A4 concentration of $2.5 \mathrm{mg} / \mathrm{mL}$ with an OCT concentration of $100 \mathrm{mM}$ to determine the most effective incubation time within a linear range. To determine the optimal protein concentration of recombinant CYP3A4 within a linear range, different recombinant CYP3A4 concentrations were used, such as $1.25,2.5,5,10$, and $20 \mathrm{mg} / \mathrm{mL}$ using an incubation time of $10 \mathrm{~min}$ and an OCT concentration of $100 \mathrm{mM}$. Based on the optimized CYP3A4 protein concentration at different reaction times, different OCT concentrations $(20,50,100,200$, and $400 \mathrm{mM})$ were added to the reaction mixture and the experiment was then performed as described above.

\section{P-gp, MRP2, and CYP3A4 expression in the rat intestinal mucosa}

Upper jejunum samples from normal (Group N, $\mathrm{n}=3$ ) and $\mathrm{PH}$ (Group $\mathrm{PH}, \mathrm{n}=3$ ) rats were used to assess the expression of P-gp, MRP2, and CYP3A4 by reverse transcription-polymerase chain reaction (RT-PCR), western blotting, and immunohistochemistry.

\section{$R T-P C R$}

RT-PCR was performed as previously described [48]. Jejunum tissue samples were stored in RNA stabilizer (DaLian Pauley Shield Bio-Engineering Co., Ltd) followed by rapid freezing to prevent RNA degradation. Total RNA was extracted from each perfused sample using the TRIzol reagent (Invitrogen, Shanghai, China) according to the manufacturer's protocol and was analyzed by ultraviolet spectrophotometry. A 2-step RT-PCR was performed using the Taq DNA polymerase kit (Takara, Dalian, China) according to the provided protocol, and cDNA was subsequently amplified using a GeneAmp PCR system (Techne TC512, UK). RNA samples (500 ng) were reverse transcribed and immediately amplified by PCR. Reverse transcription was performed for $10 \mathrm{~min}$ at $30{ }^{\circ} \mathrm{C}$, followed by $30 \mathrm{~min}$ at $42{ }^{\circ} \mathrm{C}$, and the samples were subsequently heated for $5 \mathrm{~min}$ at $95^{\circ} \mathrm{C}$ to terminate the reaction. $\beta$-actin (5'-GGGACCTGACAGACTACC TC- $3^{\prime}$ forward and $5^{\prime}$ - GACAGCACTGTGTTGGCA TAG- $3^{\prime}$ reverse) was used as the internal control. The primers (Takara, Dalian, China) used where the following: mdr1a-F, 5'-GATGGAATTGATAATGTGGACA-3'; mdr1a-R 5'-AAGGATCAGGAACAATAAA-3'; mdr1b-F, 5'-GAAATAATGCTTATGAATCCCAAAG- ${ }^{\prime}$; mdr1bR, 5'-GGTTTCATGGTCGTCGTCTCTTGA-3'; mrp2-F, 5'-ACCTTCCACGTAGTGATCCT -3'; mrp2-R, 5'-ACC TGCTAAGATGGACGGTC-3'; cyp3A1-F, $\quad 5^{\prime}$-GAG GAGTAATTTGCTGACAGAACCTGC-3'; cyp3A1-R, 5'-CCAGGAATCCCCTGTTTCTTGAA-3'(Additional file 1: Table S1). Quantity One (version 4.40) software (Bio-Rad, CA, USA) was used to analyze the band density on each gel. $\beta$-actin mRNA expression was used to normalize the expression of the target genes.

\section{Western blot}

Upper jejunum samples were frozen and stored in radioimmunoprecipitation (RIPA) buffer. Western blotting was performed as previously described [32]. Mouse P-gp monoclonal antibody C219 (1:75) (Thermo Scientific, Pierce Biotechnology, USA), rabbit-anti-mouse MRP2 monoclonal antibody (1:100), rabbit-anti-mouse CYP3A4 polyclonal antibody (1:1000) (Abcam, Cambridge, MA, USA), and a $\beta$-actin monoclonal antibody (1:1000) (Beijing Zhong Shan Golden Bridge Biological Technology 
CO., LTD) were used. Anti-rabbit (1:800) or anti-mouse (1:1000) horseradish peroxidase-conjugated antibody (Beyotime Institute of Biotechnology, China) was used as the secondary antibody for the final protein detection. Protein bands were visualized and photographed under transmitted ultraviolet light for semiquantitative measurements based on band densitometry. $\beta$-actin was used as the loading control.

\section{Immunohistochemistry}

Upper jejunum samples were prepared for the immunohistochemical staining as previously described [46].
Primary P-gp, MRP2, and CYP3A4 antibodies were the same as those used to perform western blotting, and used at the dilution of 1:58, 1:100 and 1:70, respectively. Phosphate-buffered saline replaced the primary antibodies in the negative controls. Yellow staining of membranes and cytoplasm indicated P-gp and MRP2 positivity, while the yellow staining only in the membrane indicated CYP3A4 positivity A total of 5 high-power microscopic fields per slide were randomly selected for signal quantification. Cell staining was scored between 1 and 4, depending on the staining intensity. The final score was defined as the staining intensity $\times$ percentage of positive cells [52]. The

\begin{tabular}{|c|c|c|}
\hline \multicolumn{2}{|c|}{ Experiments/Methods } & Groups \\
\hline \multirow[t]{2}{*}{$\begin{array}{l}\text { Pharmacokinetic } \\
\text { interaction study }\end{array}$} & $\begin{array}{l}\text { In situ jejunal } \\
\text { perfusion technique }\end{array}$ & $\begin{array}{l}\text { Healthy rats: Group A-D } \\
\text { PH rats: Group A1-D1 }\end{array}$ \\
\hline & $\begin{array}{lr}\text { In vitro } & \text { everted } \\
\text { intestinal } & \mathrm{sac} \\
\text { preparation } & \\
\end{array}$ & $\begin{array}{l}\text { Control rats: Group A-D } \\
\text { PH rats: Group A1-D1 }\end{array}$ \\
\hline \multicolumn{2}{|c|}{ Caco-2 permeability assay } & $\begin{array}{l}\text { 1)OCT; } 2) \mathrm{OCT} \text { and rhodamine } \\
123 ; 3) \mathrm{OCT}(10 \mu \mathrm{M}) \text { and probenecid }(1 \mathrm{mM})\end{array}$ \\
\hline \multicolumn{2}{|c|}{$\begin{array}{l}\text { Rat intestinal } \\
\text { preparation }\end{array}$} & $\begin{array}{lll}\text { Healthy rats:1)Group } & \mathrm{N}+\mathrm{OCT} ; & \text { 2)Group } \\
\mathrm{N}+\mathrm{OCT}+\mathrm{K} & & \\
\mathrm{PH} \quad \text { rats:1)Group } & \mathrm{PH}+\mathrm{OCT} ; & \text { 2)Group } \\
\mathrm{PH}+\mathrm{OCT}+\mathrm{K} \text {; } & & \\
\text { Control group: Group N } & & \end{array}$ \\
\hline $\begin{array}{l}\text { Recombinant } h \\
\text { P450 3A4 experin }\end{array}$ & $\begin{array}{l}\text { iman cytochrome } \\
\text { ent }\end{array}$ & $\begin{array}{l}\text { 1)Altered incubation times of } 5,10,15,20 \text { and } \\
30 \mathrm{~min} \text {; keep same CYP3A4 concentration } \\
2.5 \mathrm{mg} / \mathrm{ml} \text { and OCT concentration } 100 \mathrm{mM} \text {. } \\
\text { 2)Altered the recombinant CYP3A4 } \\
\text { concentration to } 1.25,2.5,5,10 \text { and } 20 \mathrm{mg} / \mathrm{ml} \text {; } \\
\text { keep same incubation time } 10 \mathrm{~min} \text { and OCT } \\
\text { concentration } 100 \mathrm{mM} \text {. } \\
\text { 3)Based on the optimized CYP3A4 protein } \\
\text { concentration at different reaction times, altered } \\
\text { different OCT concentrations }(20,50,100,200 \\
\text { and } 400 \mathrm{mM}) \text {. }\end{array}$ \\
\hline $\begin{array}{l}\text { RT-PCR } \\
\text { Western blotting } \\
\text { Immunohistochen }\end{array}$ & & $\begin{array}{l}\text { Normal rats: Group N } \\
\text { PH rats: Group PH }\end{array}$ \\
\hline
\end{tabular}

Fig. 1 Graphical explanation of the performed experiments/methods together with the respective groups 
mean score of 5 fields was used to compare the 5 groups. Figure 1 shows a graphical explanation of the performed experiments/methods together with the respective groups.

\section{Sample preparation for LC - MS/MS analysis}

Frozen samples were thawed at room temperature prior to their preparation. A $200-\mu \mathrm{L}$ aliquot of cell lysate containing $1 \mathrm{~mL}$ Tris, $99 \mathrm{~mL}$ D-Hank's, and $200 \mu \mathrm{L}$ methyl cyanide was mixed with the sample obtained from Caco-2 experiments. The mixture was then vortexed for $1 \mathrm{~min}$ and centrifuged at $12,000 \times g$ for $10 \mathrm{~min}$. The supernatant was transferred to a clean glass tube and evaporated to dryness at $40{ }^{\circ} \mathrm{C}$ under nitrogen. A $10-\mu \mathrm{L}$ aliquot was injected for LC-MS/MS analysis. A total of $200 \mu \mathrm{L}$ methanol was added to a 50- $\mu \mathrm{L}$ sample of plasma, and the mixture was vortexed and centrifuged as described above to remove precipitated proteins. A total of $200 \mu \mathrm{L}$ supernatant was transferred and evaporated as described for the Caco-2 samples. The residue was then diluted with $100 \mu \mathrm{L}$ mobile phase and an aliquot of $10 \mu \mathrm{L}$ was used for LC-MS/MS analysis.

\section{OCT content by LC-MS/MS}

An Agilent LC system (Agilent HP1200, Agilent Technology Inc., Palo Alto, CA, USA) was used to measure the OCT content. Isocratic chromatographic separation was performed using a Hypersil BDS-C18 column $(150 \mathrm{~mm} \times 4.6 \mathrm{~mm}$ i.d., $5 \mu \mathrm{m}$; Dalian Elite Analytical Instruments Co. Ltd., China) maintained at room temperature. A mixture of $40 \%$ methanol- $60 \%$ water with $0.1 \%$ formic acid $(60: 40, \mathrm{v} / \mathrm{v})$ was used as the mobile phase at a flow rate of $0.5 \mathrm{~mL} / \mathrm{min}$. An API 3200 triplequadrupole mass spectrometer (Applied Biosystems, Concord, Ontario, Canada) was operated with a Turbo Ionspray interface in positive ion mode. The ion spray voltage was set to $+4 \mathrm{psi}$, heater gas temperature to $500{ }^{\circ} \mathrm{C}$, nebulizer gas (Gas 1 ) at $40 \mathrm{psi}$, heater gas (Gas 2) at $40 \mathrm{psi}$, curtain gas at $10 \mathrm{psi}$, and collision gas at $16 \mathrm{psi}$.

The declustering potential was set to $30 \mathrm{~V}$ for the analyses and IS. Multiple reaction monitoring (MRM) was employed for data acquisition. The optimized MRM fragmentation transition was $\mathrm{m} / \mathrm{z} 510.2 \rightarrow \mathrm{m} / \mathrm{z}$ 120.1, with collision energy of $50 \mathrm{eV}$ for OCT. The dwell time for each transition was $200 \mathrm{~ms}$. Data processing was performed using the Analyst 1.4.1 software package (Applied Biosystems).

\section{Statistical analysis}

SPSS 11.5 software was used for statistical analysis. All measurements were expressed as mean $\pm \mathrm{SD}$. One-way analysis of variance (ANOVA) was performed to evaluate significant differences among multiple treatments for a specific parameter. A value of $p<0.05$ was considered statistically significant.

\section{Results}

P-gp and MRP2 inhibition increases jejunal OCT absorption in situ

In situ jejunal perfusion was used to determine the effect of P-gp and MRP2 inhibitors on the absorption of OCT in healthy (Groups A-D) and PH (Groups A1-D1) rats. The OCT level in Group D (receiving OCT plus both verapamil hydrochloride, a P-gp inhibitor, and probenecid, an MRP2 inhibitor) was significantly increased compared with its level in the Group A, B, and C $(p<0.05$, Fig. 2a). The OCT content in Group B (OCT plus verapamil hydrochloride) was also significantly increased compared with its content in the Group C (OCT plus probenecid) $(p<0.05)$. Similar results were obtained in $\mathrm{PH}$ rats (Fig. $2 \mathrm{~b}$ ). The OCT absorption was lower under each condition used in $\mathrm{PH}$ rats compared to its absorption in normal rats $(p<0.05)$. The AUC in Group B, C, and D was $521.08 \%, 418.95 \%$, and $618.40 \%$ respectively, of the correspondent control (Group A; OCT only), while the AUC of Group B1, C1, and D1 was $384.61 \%, 236.28 \%$, and $461.78 \%$ respectively, of the correspondent control group (Group A1). In turn, the AUC of group A1 was $96 \%$ of group A. These results indicated that P-gp and, to a lesser extent, MRP2 activity inhibited OCT absorption in situ. Moreover, these results indicated that intestinal OCT absorption was impaired in $\mathrm{PH}$ rats, suggesting that other mechanisms besides P-gp and MRP2 were potentially involved in this process.

\section{P-gp and MRP2 inhibition increases OCT uptake in the everted intestinal sac model}

To confirm the involvement of P-gp and MRP2 in the intestinal OCT absorption and assess the difference between control and $\mathrm{PH}$ rats, the rat everted intestinal sac in vitro model was used. The OCT concentration in Group D was significantly increased compared with its concentration in Group A, B, and $C(p<0.05$, Fig. 2c). Moreover, the OCT content in Group B was significantly increased compared with its content in Group $\mathrm{C}(p<0.05)$. Similar results were observed in $\mathrm{PH}$ rats (Fig. 2d). Moreover, the OCT level in PH rats was significantly decreased compared with that in the corresponding control groups $(p<0.05)$. The AUC value in Group B, C, and D was $176.22 \%, 151.39 \%$, and $220.63 \%$ respectively, of the correspondent control group (Group A). The AUC value in Group B1, C1, and D1 was $151.82 \%$, $128.23 \%$, and $165.33 \%$ respectively, of the correspondent control group (Group A1). The AUC of Group A1 was $21.54 \%$ of the one in Group A. Although clear differences in the degree of OCT transport were observed 

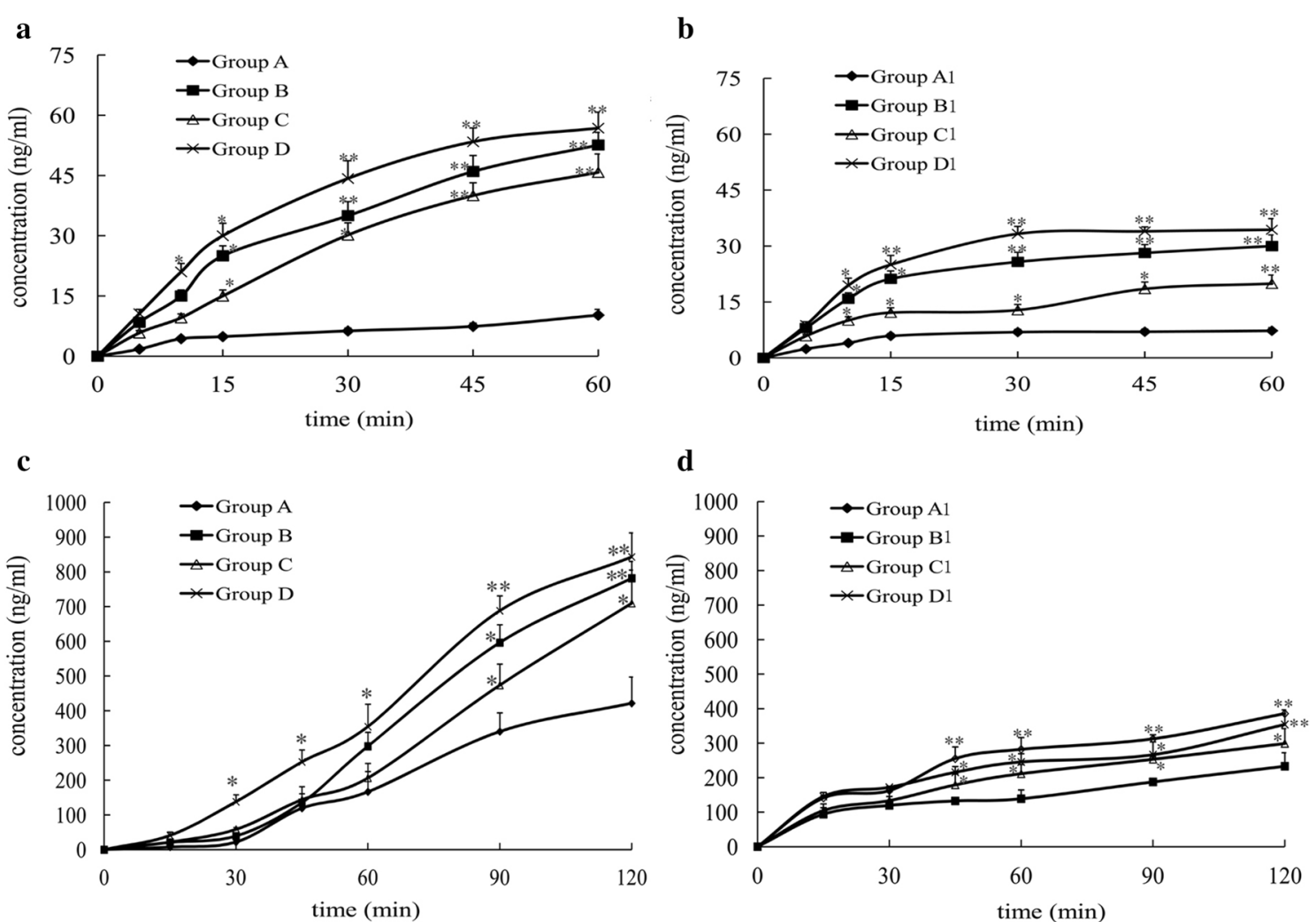

Fig. 2 Effects of P-gp and MRP2 inhibition on the time profile of OCT transport in the intestine. a OCT absorption kinetics in in situ jejunal perfusion experiments in healthy rats; $\mathbf{b}$ OCT absorption kinetics in in situ jejunal perfusion experiments in $\mathrm{PH}$ rats; $\mathbf{c}$ OCT absorption kinetics in the everted intestinal sac preparation in healthy rats; $\mathbf{d}$ OCT absorption kinetics in the everted intestinal sac preparation in PH rats; Group A, control group; Group B, OCT plus verapamil hydrochloride; Group C, OCT plus probenecid; Group D, OCT plus verapamil hydrochloride plus probenecid. Results are expressed as mean \pm S.D. $(n=4) .{ }^{*} p<0.05$ versus control (Group A, Group A1), ${ }^{* *} p<0.01$ versus control (Group A, Group A1)

between these experiments and in situ jejunal perfusion experiments (probably due to the lack of physiological environment in the everted sac preparation), the above results confirmed that rats with $\mathrm{PH}$ had a reduced intestinal OCT absorption.

\section{Cell-based OCT permeability assay}

A bi-directional Caco-2 cell permeability assay was further performed to examine the effect of P-gp and MRP2 inhibition on OCT absorption (i.e. apical to basolateral -A/B- transport and secretion - B/A- transport).The assay was performed using 1,10 , and $50 \mu \mathrm{M}$ OCT in the presence or absence of rhodamine $123(1 \mathrm{mM})$ and probenecid (1 $\mathrm{mM})$, to inhibit P-gp and MRP2, respectively. Table 1 shows the measured permeability coefficient $\left(\mathrm{P}_{\text {app }}\right)$ and flux ratio (permeability direction rate, PDR; $\mathrm{B}$ to $\mathrm{A} / \mathrm{A}$ to $\mathrm{B}$ ). Overall, the results indicated that $\mathrm{P}$-gp and MRP2 effectively mediated OCT transport in Caco-2 cells, as demonstrated by the PDR $>1.5$ indicating active drug transport. The determination of OCT at a dose of $1 \mu \mathrm{M}$ was unreliable, as some sample points approached the quantitative limit of the triple-quadrupole mass spectrometer assay. In turn, $50 \mu \mathrm{M}$ OCT was close to the saturation concentration, and it did not yield an accurate flux measurement. Reliable data were instead recorded with $10 \mu \mathrm{M}$ OCT, roughly equivalent to a clinical dose of $80 \mathrm{mg}$ [36]. The secretion (B to A flux) of OCT by Caco-2 monolayers was 4.4 times greater than its absorption (A to B flux) (Table 1). $P_{\text {app (A-B) }}$ significantly increased when P-gp or MRP2 was inhibited, particularly when P-gp and MRP2 were simultaneously inhibited. In contrast, $P_{\text {app }}$ (B-A) was significantly decreased by each individual inhibitor, and the effect was even stronger upon co-inhibition. These results were consistent with P-gp and MRP2 being predominantly located at the apical cell membrane [53], therefore acting to limit drug absorption.

\section{CYP3A-mediated OCT metabolism is increased in rat intestinal microsomes}

OCT metabolism by CYP3A was assessed in intestinal microsomes isolated from healthy $(\mathrm{N})$ and $\mathrm{PH}$ rats. 
Table 1 Effect of P-gp and MRP2 inhibition on OCT transport by Caco-2 cells

\begin{tabular}{|c|c|c|c|c|c|c|c|}
\hline \multirow[t]{2}{*}{ Inhibition } & & \multicolumn{2}{|l|}{ OCT $1 \mu \mathrm{M}$} & \multicolumn{2}{|l|}{ OCT $10 \mu \mathrm{M}$} & \multicolumn{2}{|l|}{ OCT $50 \mu \mathrm{M}$} \\
\hline & & A-B & B-A & A-B & B-A & $A-B$ & B-A \\
\hline \multirow[t]{2}{*}{ MRP2 } & $P_{\text {app }}\left(\times 10^{-6} \mathrm{~cm} / \mathrm{s}\right)$ & $0.007 \pm 0.001$ & $0.006 \pm 0.001$ & $0.149 \pm 0.016^{a}$ & $0.31 \pm 0.025^{b}$ & $0.353 \pm 0.032$ & $1.13 \pm 0.097$ \\
\hline & $\mathrm{PDR}(\mathrm{B}-\mathrm{A} / \mathrm{A}-\mathrm{B})$ & \multicolumn{2}{|c|}{0.9} & \multicolumn{2}{|c|}{2.1} & \multicolumn{2}{|c|}{3.2} \\
\hline \multirow[t]{2}{*}{ P-gp } & $P_{\text {app }}\left(\times 10^{-6} \mathrm{~cm} / \mathrm{s}\right)$ & $0.010 \pm 0.001$ & $0.012 \pm 0.002$ & $0.168 \pm 0.018^{a}$ & $0.297 \pm 0.024^{b}$ & $1.192 \pm 0.072$ & $1.040 \pm 0.084$ \\
\hline & $\mathrm{PDR}(\mathrm{B}-\mathrm{A} / \mathrm{A}-\mathrm{B})$ & \multicolumn{2}{|c|}{1.2} & \multicolumn{2}{|c|}{1.8} & \multicolumn{2}{|c|}{0.9} \\
\hline \multirow[t]{2}{*}{ MRP2 and P-gp } & $P_{\text {app }}\left(\times 10^{-6} \mathrm{~cm} / \mathrm{s}\right)$ & $0.022 \pm 0.002$ & $0.006 \pm 0.001$ & $0.368 \pm 0.055^{a, c}$ & $0.193 \pm 0.021^{b, c}$ & $1.725 \pm 0.138$ & $0.981 \pm 0.082$ \\
\hline & $\mathrm{PDR}(\mathrm{B}-\mathrm{A} / \mathrm{A}-\mathrm{B})$ & \multicolumn{2}{|c|}{0.3} & \multicolumn{2}{|c|}{0.5} & \multicolumn{2}{|c|}{0.6} \\
\hline \multirow[t]{2}{*}{ Control } & $P_{\text {app }}\left(\times 10^{-6} \mathrm{~cm} / \mathrm{s}\right)$ & $0.005 \pm 0.001$ & $0.021 \pm 0.003$ & $0.127 \pm 0.015$ & $0.565 \pm 0.073^{c}$ & $0.23 \pm 0.021$ & $1.334 \pm 0.160$ \\
\hline & $P D R(B-A / A-B)$ & \multicolumn{2}{|c|}{4.1} & \multicolumn{2}{|c|}{4.4} & \multicolumn{2}{|c|}{5.8} \\
\hline
\end{tabular}

Results are expressed as mean $\pm S D ; n=4$ per treatment

A-B, Apical-to-Basolateral; B-A, Basolateral-to-Apical

$P_{a p p}$, permeability coefficient; $P D R$, permeability direction rate

a Indicates $p<0.05$ for: $\mathrm{P}_{\text {app }}\left(\mathrm{A}\right.$ to $\mathrm{B}$ ) of MRP2 and $\mathrm{P}$-gp inhibition versus $\mathrm{P}_{\text {app }}\left(\mathrm{A}\right.$ to $\mathrm{B}$ ) of MRP2 or P-gp inhibition; $\mathrm{P}_{\text {app }}\left(\mathrm{A}\right.$ to $\mathrm{B}$ ) of $\mathrm{P}$-gp inhibition versus control; and $\mathrm{P}_{\text {app }}$ (A to $B$ ) of MRP2 inhibition versus Control

${ }^{b}$ Indicates $p<0.05$ for $\mathrm{P}_{\text {app }}\left(\mathrm{B}\right.$ to $\mathrm{A}$ ) versus $\mathrm{P}_{\text {app }}$ ( $\mathrm{A}$ to $\mathrm{B}$ ) upon inhibition of MRP2 or $\mathrm{P}$-gp and combined inhibition of MRP2 and $\mathrm{P}$-gp

c Indicates $p<0.01$ for: $\mathrm{P}_{\text {app }}\left(\mathrm{A}\right.$ to $\mathrm{B}$ ) of $\mathrm{MRP} 2$ and $\mathrm{P}$-gp inhibition versus Control; $\mathrm{P}_{\text {app }}$ ( $\mathrm{B}$ to $\mathrm{A}$ ) of $\mathrm{MRP} 2$ and $\mathrm{P}$-gp inhibition versus control; and $\mathrm{P}_{\text {app }}$ ( $\mathrm{B}$ to $\left.\mathrm{A}\right)$ control versus $P_{a p p}(A$ to $B$ ) control (control $=10 \mu \mathrm{M} \mathrm{OCT}$ )

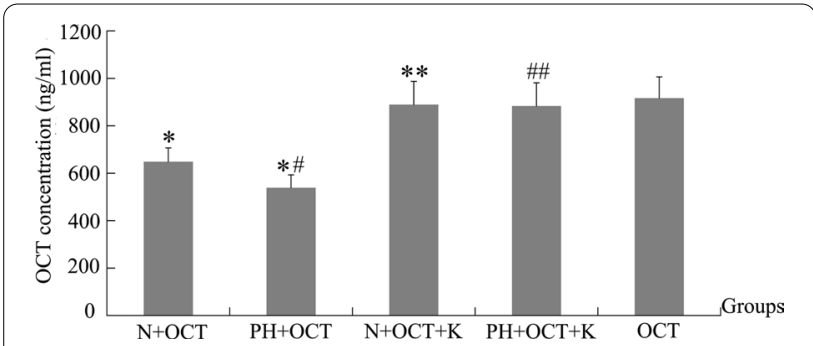

Fig. 3 OCT metabolism by CYP3A in rat intestinal microsomes. CYP3A activity was measured using a fluorescent detection kit, and OCT content was determined at different times by LC-MS/MS. Results are expressed as mean \pm S.D. $(n=6) .{ }^{*} p<0.01$, Group $N+O C T$ versus Group OCT, Group PH+ OCT versus Group OCT; ${ }^{* *} p<0.01$, Group $\mathrm{N}+\mathrm{OCT}+\mathrm{K}$ versus Group N+OCT; \#p $<0.05$, Group PH+ OCT versus Group N+OCT; \#\# $p<0.01$, Group PH+OCT + K versus Group $\mathrm{PH}+\mathrm{OCT}$. Group OCT, OCT alone without microsomes; N, Normal microsomes; $\mathrm{PH}, \mathrm{PH}$ microsomes; $\mathrm{K}$, ketoconazole

CYP3A activity was approximately $280 \mathrm{pmol} /\left(\mathrm{mg}^{*} \mathrm{~min}\right)$ in microsomes from normal rats, while its activity was approximately $350 \mathrm{pmol} /\left(\mathrm{mg}^{*} \mathrm{~min}\right)$ in microsomes from $\mathrm{PH}$ rats. The OCT level was significantly lower in the $\mathrm{PH}+\mathrm{OCT}$ group than in the $\mathrm{N}+\mathrm{OCT}$ group $(p<0.05)$, and significantly and equally increased in both groups in the presence of the CYP3A inhibitor ketoconazole $(p<0.01)$. These results indicated that OCT was metabolized by CYP3A, and the expression or activity of this enzyme was increased in the intestinal tissue of rats with PH (Fig. 3).
OCT is metabolized by recombinant human CYP3A4

Next, the potential involvement of CYP3A4, the cytochrome $\mathrm{P} 450$ isoform most commonly involved in drug metabolism in humans, in OCT metabolism was determined. No changes in the activity of recombinant human CYP3A4 were observed when the enzyme was pre-incubated with OCT (400 mM). Thus, the OCT concentration used in this study did not inhibit CYP3A4 activation. An inverse linear correlation was observed between incubation time and residual OCT concentration, where the most effective incubation time was $10 \mathrm{~min}$ (Fig. $4 \mathrm{a}-\mathrm{c}$ ). An inverse linear relationship was also observed between recombinant CYP3A4 protein concentration and residual OCT concentration, where the most effective protein concentration was $2.5 \mathrm{mg} / \mathrm{mL}$. Under these conditions, the residual OCT content decreased in line with a decrease in the initial concentration of OCT $(p<0.05)$, and many different metabolites were observed via LC-MS/MS. These results demonstrated that CYP3A4 metabolized OCT.

\section{P-gp, MRP2, and CYP3A4 expression is increased in the intestinal mucosa of rats with $\mathrm{PH}$}

RT-PCR and western blot analysis revealed that P-gp, MRP2, and CYP3A4 mRNA and protein expression was significantly higher in $\mathrm{PH}$ rats compared to the normal ones $(p<0.05)$ (Fig. 5a, b). On the other hand, the immunohistochemical analysis revealed significantly higher P-gp/MRP2/CYP3A4 scores in $\mathrm{PH}$ samples compared with the scores in the controls $(p<0.05)$ (Fig. $5 c)$. These results demonstrated that $\mathrm{P}$-gp, MRP2, and CYP3A4 
$\mathbf{a}$

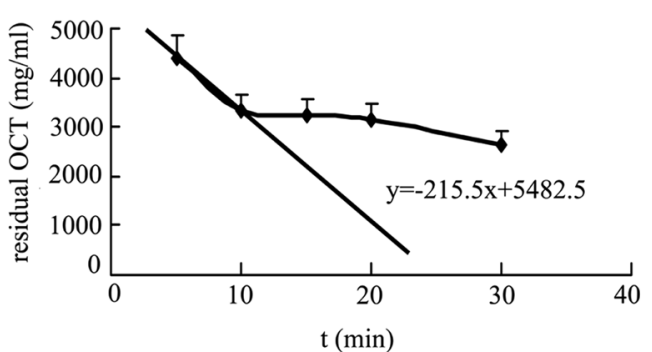

c

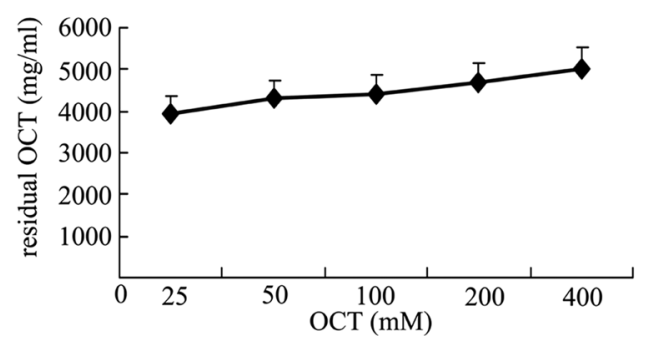

b

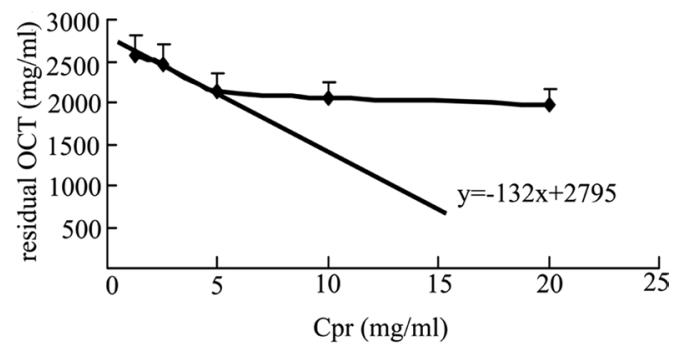

Fig. 4 OCT metabolism by recombinant human CYP3A4. a Correlation between incubation time and residual OCT concentration; the most effective incubation time was $10 \mathrm{~min}$. b Correlation between recombinant CYP3A4 and residual OCT concentration; the most effective CYP3A4 concentration was $2.5 \mathrm{mg} / \mathrm{mL}$. c Plot of residual OCT content as a function of the initial OCT concentration

were upregulated in the intestinal mucosa of rats with BDL-induced PH.

\section{Discussion}

In this study, the mechanism mediating OCT absorption was studied in a rat model of biliary cirrhosis with $\mathrm{PH}$ induced via BDL. This method was used to reduce cholestasis in the intestine, easily inducing $\mathrm{PH}$ conditions, and diminishing rat fatality. A previous study showed that the establishment of a portosystemic shunt decreases hepatic first-pass effects under PH conditions [17].

As the intestinal first-pass effect also greatly influences the oral absorption and bioavailability of drugs, our next experiments addressed OCT absorption mechanisms in the jejunum, the main site of OCT absorption in the intestine [47], in both control and $\mathrm{PH}$ rats.

$\mathrm{P}$-gp is an important member of ATP binding cassette transporter family $(\mathrm{ABC}) . \mathrm{ABC}$ is an important factor affecting the drug action during the body process in vivo, and $\mathrm{P}$-gp is the most important transporter. MRP is a carrier protein with $\mathrm{ABC}$ and plays an important role in the dynamic changes of drugs in vivo. Like P-gp, MRP2 can restrict the absorption of substrates through the intestinal tract, forming an intestinal absorption barrier and is the main target of excretion of drugs through intestine [18-21]. Previous studies showed that P-gp and MRP-2 inhibit the passage of OCT through the blood-brain barrier and proximal renal tubules $[21,42]$. Considering that the two efflux transporters can significantly inhibit intestinal absorption of many drugs in the intestine, our hypothesis was that P-gp and MRP-2 might also play an important role in the first-pass intestinal effect of OCT. CYP450 enzyme system is the most important phase I metabolic enzyme in vivo. It participates in the metabolic transformation and elimination of endogenous and exogenous substances, especially CYP3A4. As a major enzyme system, CYP3A4 is involved in the first-pass effect process of oral drugs, which is also an important factor affecting drug-drug interaction [43]. P-gp, MRP2, and CYP3A4 often have overlapping substrates; thus, they have synergistic effects on the same substrate. Therefore, our further speculation was that CYP3A4 might also affect the metabolism and absorption of OCT in the intestinal tract, playing an inhibitory role together with the efflux transporters.

Our in situ jejunal perfusion and everted intestinal sac studies demonstrated that the absorbed OCT concentrations were higher when P-gp and MRP2 inhibitors were co-administered than when each drug was administered alone. In addition, P-gp inhibition had a stronger effect than MRP2 inhibition, suggesting that P-gp was the main driver of OCT efflux in the rat intestine. Intestinal OCT uptake was impaired in $\mathrm{PH}$ rats, and this phenomenon could be explained by the increased expression of P-gp, MRP2, and CYP3A, as detected by RT-PCR, western blotting, and immunohistochemistry. A previous study showed that OCT inhibits MRP2 [54], suggesting 
a

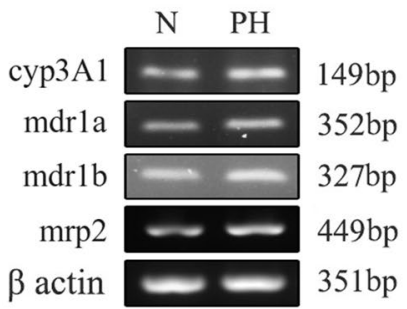

b

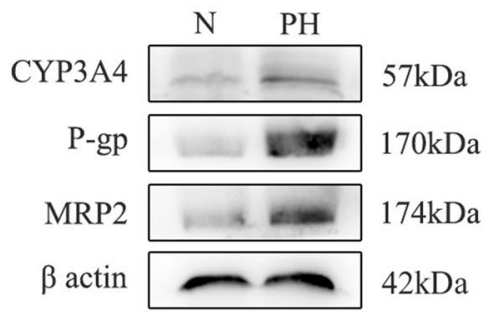

c

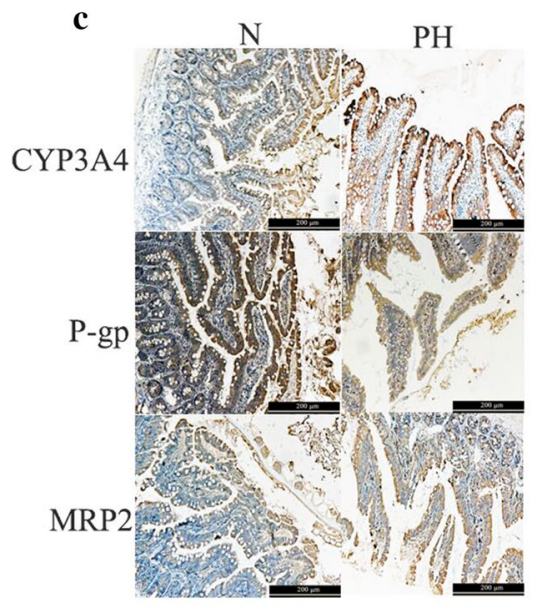

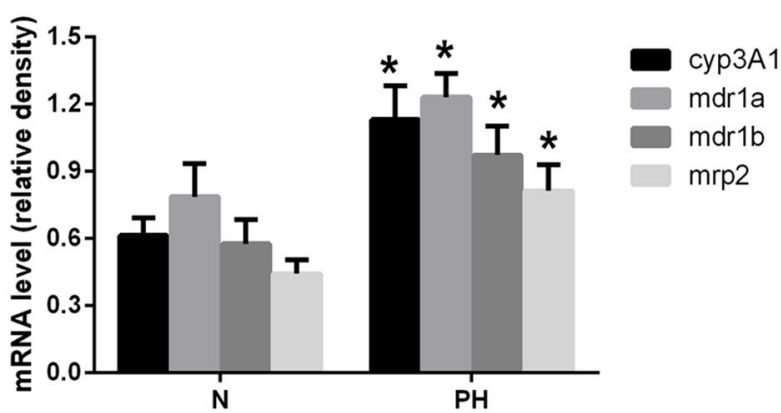
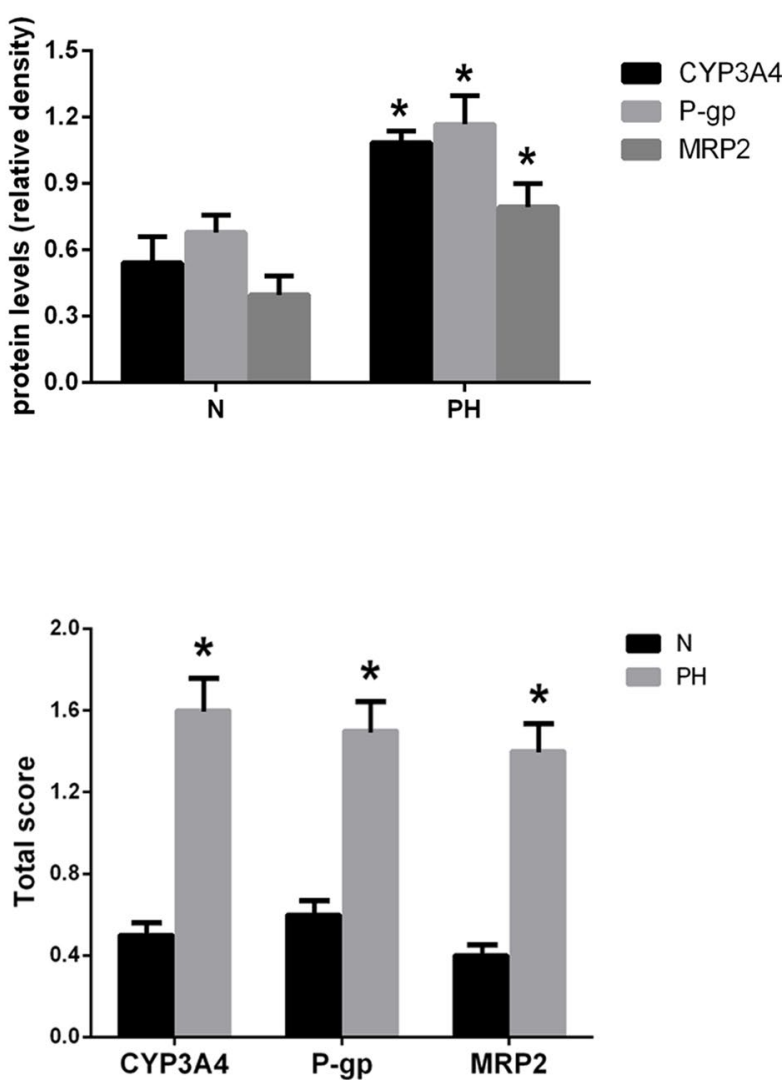

Fig. 5 P-gp, MRP2, and CYP3A4 expression in the intestinal mucosa of normal and PH rats. a RT-PCR results showing cyp3A1, MDR1 (mdr1a, mdr1b), and mrp2 mRNA expression in the intestines of normal (Group N) and PH (Group PH) rats. b Western blot showing CYP3A4, P-gp, and MRP2 protein expression in rat intestine. $\mathbf{c}$ Immunohistochemical detection of CYP3A4, P-gp, and MRP2 in rat intestine (100x magnification). Results are expressed as mean \pm S.D. $(n=3) .{ }^{*} p<0.05$, Group PH versus Group N

that MRP2 has minor or no influence on OCT absorption, which is in contradiction with our results. However, our results showed that the inhibitory effect of OCT on MRP2 was weaker compared with the enhanced firstpass intestinal effects of P-gp, MRP2, and CYP3A4 on $\mathrm{PH}$ condition, thus inducing mal-absorption of OCT. In addition, our results highlighted that P-gp was the main driver of OCT efflux in the rat intestine, compared to MRP2, thus resulting in a greater effect on OCT absorption, thus being in accordance with the previous study [54].

The involvement of both P-gp and MRP2 in OCT absorption was further demonstrated in Caco-2 cell transport assay. Human colon cancer cell line Caco-2 is a commonly used model for studying drug transporters. Caco- 2 cell model has been widely used in the study of intestinal absorption of drug molecules in vitro due to its similar morphological and biochemical properties to intestinal epithelial cells. Previous experiments 
confirmed that MDR1 and MRP2 are highly expressed in Caco-2 cells [55]. These cells not only reproduce the intestinal drug absorption, but also reflect the permeability of drugs through intestinal transmembrane transport [56]. Therefore, Caco-2 cell line is the ideal model for this experiment.

Our rat intestinal microsome study also suggested an increased CYP3A activity in PH rats than in normal rats. OCT was also found to be metabolized by recombinant human cytochrome P450 3A4 (CYP3A4), in a process blocked by ketoconazole. Ketoconazole inhibits a wide range of CYP enzymes, but at a concentration of $10 \mu \mathrm{M}$, like the one used in this work, is selective for CYP3A4 and CYP3A5 [57]. Therefore, our hypothesis was that OCT might be a substrate of CYP3A4.

OCT concentrations absorbed in the everted intestinal sac model were significantly higher than those measured in the in situ intestinal perfusion model. This difference could be due to the absence of a physiological environment, such as lack of peristalsis and intestinal microflora. CYP expression may also change $e x$-vivo, leading to individual differences in pharmacokinetics [58]. Previous studies revealed that changes in efflux transporters and metabolic enzymes occur in both the intestine and liver during liver disease. P-gp expression and CYP isoenzymatic activity in the small intestine are also enhanced in liver fibrosis, contributing to the decreased bioavailability and increased elimination of ofloxacin after oral administration [6]. A previous study also demonstrated that the expression of hepatic efflux transporters is upregulated in liver failure induced by toxic levels of acetaminophen or by primary biliary cirrhosis (PBC). Hepatic efflux decreases the retention of the by-products of cellular injury and bile constituents within hepatocytes. In addition, the increased expression of efflux proteins is a critical response to hepatic damage to protect the liver from additional injury [7]. A study in patients with PBC at an advanced-stage revealed that the export pump MRP2 is preserved and the MDR P-gp (MDR1, MDR3) is increased in canalicular liver plasma membranes, leading to the downregulation of the basolateral uptake systems. The maintenance or upregulation of canalicular and basolateral efflux pumps may represent adaptive mechanisms to limit the accumulation of toxic biliary products [8]. Cholestatic liver disease and increased concentration of serum bile acids are known as triggering various adaptive responses, including the induction of hepatic, intestinal, and renal bile acid transport proteins [9]. Results of a previous study indicated that the increased expression or activity of export pumps and CYP enzymes may occur in the intestine or even in the liver in cases of cirrhosis complicated by $\mathrm{PH}$, which was actually the same discovered in this work. Previous studies primarily focused on investigating P-gp and CYP3A4 inhibition to facilitate drug transport $[10,11,46]$. Our study also revealed that MRP2 contributed to the intestinal first-pass effect on OCT bioavailability in addition to P-gp and CYP3A4. Thus, the inhibition of P-gp, MRP2, and CYP3A4 might be a promising strategy to effectively decrease $\mathrm{PH}$ via oral administration of OCT.

Decreased hepatic levels of P-gp, MRP2, and CYP enzymes during the development of injuries such as Child's class C cirrhosis or PBC III [12-14] have been reported. In general, drug dosages should be decreased in patients with severe cirrhosis [15]. Changes in transporter expression in the liver are also responsible for cholestasis and are the result of various factors. The downregulation of hepatobiliary transport systems is observed in inflammation-induced cholestasis in humans, while transporter expression does not change in anicteric cholestasis during PBC stages I or II [16]. However, no study investigated the potential alteration in P-gp, MRP2, or CYP3A4 expression or activity in the intestine. The BDL cirrhosis model used in our study induced $\mathrm{PH}$ via extrahepatic obstruction without severe liver damage, as previously reported [59]. Thus, while previous studies reported alterations in P-gp, MRP2, and CYP3A4 in severe liver injury, hepatic expression and activity of exporters and CYP enzymes may not be significantly altered in the BDL model.

The current study did not address the mechanisms by which P-gp, MRP2, or CYP3A4 expression and/or activity are dysregulated in the intestine of $\mathrm{PH}$ rats. The pregnane X Receptor (PXR)-Retinoid X Receptor alpha stimulates CYP3A4 transcription through the activation of the CYP3A4 promoter [60, 61]. P-gp is also regulated by nuclear receptors such as PXR [62], ERK-FOXO 3a [63], while MRP2 is regulated by protein kinase $C$, radixin, nuclear factor $\mathrm{kB}$, human cAMP response element-binding protein, and the CAATT box enhancer binding protein [64-66]. Further studies are planned to investigate the molecular mechanism underlying the alteration in drug efflux transporters and detoxifying enzymes associated with $\mathrm{PH}$. In addition, we are aware of the difficulty to evaluate a proper oral administration of OCT by P-gp, MRP2, and CYP3A4 inhibition. Some aspects need to be explored in further details, such as the importance of these transporters and enzymes for hepatic/renal excretion of OCT, drug-drug interactions, and appropriate drug-therapy titration.

\section{Conclusions}

In conclusion, our work demonstrated that the decreased oral bioavailability of OCT was potentially related to the increased expression of P-gp, MRP2, and the metabolic 
enzyme CYP3A4, which increased the intestinal firstpass effect on OCT, thus limiting its anti-portal hypertensive efficacy. Targeted inhibition of P-gp, MRP2, and CYP3A4 might increase OCT oral absorption to effectively treat $\mathrm{PH}$.

\section{Supplementary information}

Supplementary information accompanies this paper at https://doi. org/10.1186/s12876-020-01532-4.

Additional file 1: Table S1. The details of RT-PCR primers

\section{Abbreviations}

PH: Portal hypertension; OCT: Octreotide; BDL: Bile duct ligation; P-gp: P-glycoprotein; MRP2: Multidrug resistance-associated protein 2; CYP3A4: Cytochrome P450 3A4; KRB: Krebs-Ringer bicarbonate buffer; AUC: Area under curve; TEER: Transepithelial electrical resistance; PDR: Permeability direction rate; PPB: Potassium phosphate buffer; RT-PCR: Reverse transcription-polymerase chain reaction; RIPA: Radio-immunoprecipitation assay; MRM: Multiple reaction monitoring; PBC: Primary biliary cirrhosis; PXR: Pregnane X Receptor.

\section{Acknowledgements}

Not applicable.

\section{Authors' contributions}

XYS, ZJD, and QYC designed the experiments; XYS, SXT and BBH performed the experiments, analyzed the data, and wrote the manuscript; $X Y S, Z L, S X T$, $\mathrm{YL}, \mathrm{SCH}$, and QMW performed the experiments and collected the data; ZJD and QYC revised the manuscript. Each author has made an important scientific contribution to the study and is familiar with the primary data. All authors read and approved the final manuscript.

\section{Funding}

This study was supported by grants from the National Natural Science Foundation of China (No. 30970886) and the Science and Technology Project of Dalian City (No.2008E13SF193). ZJD was in charge of the two projects. XYS participated in their design.

\section{Availability of data and materials}

The datasets used and/or analyzed during the current study are available from the corresponding author on reasonable request.

\section{Ethics approval and consent to participate}

This study was performed in strict accordance with the ethical standards of the International Council for Laboratory Animal Science. All animal experiments were conducted in accordance with the protocols approved by the Experimental Animal Ethical Committee of Dalian Medical University (No. L20180301).

\section{Consent for publication}

Not applicable.

\section{Competing interests}

The authors declare that they have no competing interests.

\section{Author details \\ ${ }^{1}$ Department of Gastroenterology, First Affiliated Hospital of Dalian Medical University, Dalian 0086-116011, China. ${ }^{2}$ Department of Invasive Technology, Affiliated Zhongshan Hospital of Dalian University, Dalian, China. ${ }^{3}$ Depart- ment of Dermatology, Second Affiliated Hospital of Dalian Medical University, Dalian, China. ${ }^{4}$ Department of Clinical Pharmacology, College of Pharmacy, Dalian Medical University, Dalian, China. ${ }^{5}$ Department of Breast Surgery, Hospital of Chinese Medical University, Liaoning Provincial Cancer Institute and Hospital, Shenyang, China. ${ }^{6}$ Department of Neurosurgery, Affiliated Zhongshan Hospital of Dalian University, Dalian, China.}

Received: 13 December 2018 Accepted: 9 November 2020

Published online: 06 January 2021

\section{References}

1. Seo YS. Prevention and management of gastroesophageal varices. Clin Mol Hepatol. 2018;24(1):20-42.

2. de Franchis R. Baveno VI Faculty: expanding consensus in portal hypertension: report of the Baveno VI Consensus Workshop: stratifying risk and individualizing care for portal hypertension. J Hepatol. 2015;63(3):743-52.

3. Rockey DC. Pharmacologic therapy for gastrointestinal bleeding due to portal hypertension and esophageal varices. Curr Gastroenterol Rep. 2006;8(1):7-13.

4. Schiedermaier P, Koch L, Stoffel-Wanger B, Layer G, Sauerberuch T. Effect of proparnolol and depot lanreotide SR on postprandial and circadian portal haemodynamics in cirrhosis. Aliment Pharmacol Ther. 2003;18:777-84.

5. Garcia-Tsao G, Grace ND, Groszmann RJ, Conn HO, Bermann MM, Patrick MJ, Morse SS, Alberts JL. Short-term effects of propranolol on portal venous pressure. Hepatology. 1986;6:101-6.

6. Wang H, Liao ZX, Chen M, Hu XL. Effects of hepatic fibrosis on ofloxacin pharmacokinetics. Pharmacol Res. 2006;53:28-34.

7. Barnes SN, Aleksunes LM, Augustine L, Scheffer GL, Goedken MJ, Jakowski $A B$, Pruimboom-Brees IM, Cherrington NJ, Manautou JE. Induction of hepatobiliary efflux transporters in acetaminophen-induced acute liver failure cases. Drug Meta Dispos. 2007;35:1963-9.

8. Zollner G, Fickert P, Silbert D, Fuchsbichler A, Marschall HU, Zatloukal K, Denk H, Trauner M. Adaptive changes in hepatobiliary transporter expression in primary biliary cirrhosis. J Hepatol. 2003;38:717-27.

9. Kneuer C, Honscha W, Gäbel G, Honscha KU. Adaptive response to increased bile acids: induction of MDR1 gene expression and P-glycoprotein activity in renal epithelial cells. Pflugers Arch. 2007;454:587-94

10. Cho YA, Lee W, Choi JS. Effects of curcumin on the pharmacokinetics of tamoxifen and its active metabolite, 4-hydroxytamoxifen, in rats: possible role of CYP3A4 and P-glycoprotein inhibition by curcumin. Pharmazie. 2012;67:124-30.

11. Scaglione F. New oral anticoagulants: comparative pharmacology with vitamin Kantagonists. Clin Pharmacokinet. 2013;52:69-82.

12. Kojima H, Nies AT, König J, Hagmann W, Spring H, Uemura M, Fukui H, Keppler D. Changes in the expression and localization of hepatocellular transporters and radixin in primary biliary cirrhosis. J Hepatol. 2003;39:693-702.

13. Kullak-Ublick GA, Baretton GB, Oswald M, Renner EL, Paumgartner G, Beuers U. Expression of the hepatocyte canalicular multidrug resistance protein(MRP2) in primary biliary cirrhosis. Hepatol Res. 2002;23:78-82.

14. Eldesoky ES, Kamel SI, Farghaly AM, Bakheet MY, Hedaya MA, Siest JP. Study of the urinary ratio of 6 beta-hydroxycortisol/ cortisol as a biomarker of CYP3A4 activity in Egyptian patients with chronic liver diseases. Biomark Insights. 2007;1:157-64.

15. Orlando R, Piccoli P, De Martin S, Padrini R. Palatini P: Effect of the CYP3A4 inhibitor erythromycin on the pharmacokinetics of lignocaine and its pharmacologically active metabolites in subjects with normal and impaired liver function. Br J Clin Pharmacol. 2003;55:86-93.

16. Zollner G, Fickert P, Zenz R, Fuchsbichler A, Stumptner C, Kenner L, Ferenci P, Stauber RE, Krejs GJ, Denk H, Zatloukal K, Trauner M. Hepatobiliary transporter expression in percutaneous liver biopsies of patients with cholestatic liver diseases. Hepatology. 2001;33:633-46.

17. Verbeeck RK. Pharmacokinetics and dosage adjustment in patients with hepatic dysfunction. Eur J Clin Pharmacol. 2008;64:1147-61.

18. Ghosh R. D, Chakraborty P, Banerjee K, Adhikary A, Sarkar A, Chatterjee M, Das T, Choudhuri SK: The molecular interaction of a copper chelate with human P-glycoprotein. Mol Cell Biochem. 2012;364:309-20.

19. Gu L, Chen J, Synold TW, Forman BM, Kane SE. Bioimaging real-time PXR-dependent mdr1a gene regulation in mdr1a.fLUC reporter mice. J Pharmacol Exp Ther. 2013;345:438-845.

20. Liu W, Feng Q, Li Y, Ye L, Hu M, Liu Z. Coupling of UDP- glucuronosyltransferases and multidrug resistance-associated proteins is responsible for the intestinal disposition and poor bioavailability of emodin. Toxicol Appl Pharmacol. 2012;265:316-24. 
21. Gutmann H, Miller DS, Droulle A, Drewe J, Fahr A, Fricker G. P-glycoprotein- and mrp2- mediated octreotide transport in renal proximal tubule. Br J Pharmacol. 2000;129:251-6.

22. Bosch J, Kravetz D, Rodes J. Effects of somatostatin on hepatic and systemic hemodynamics in patients with cirrhosis of the liver: comparison with vasopressin. Gastroenterology. 1981;80(3):518-25.

23. Lamberts SW, van der Lely AJ, Hofland LJ. New somatostatin analogs: will they fulfil old promises? Eur J Endocrinol. 2002;146:701-5.

24. Zhai Z. Octreotide decreases portal pressure: Hepatic stellate cells may play a pivotal role. Afr J Biotechnol. 2010;9:1833-8.

25. Eroglu Y, Emerick KM, Whitington PF, Alonso EM. Octreotide therapy for control of acute gastrointestinal bleeding in children. J Pediatr Gastroenterol Nutr. 2004;38(1):41-7.

26. Garcia-Tsao G, Sanyal AJ, Grace ND, Carey WD. Prevention and management of gasroesophageal varices and varicel hemorrhage. Am J Gastroenterol. 2007;102(9):2086-102

27. Qureshi W, Adler DG, Davila R, Egan J, Hirota W, Leighton J, Rajan E, Zuckerman MJ, Fanelli R, Wheeler-Harbaugh J, Baron TH, Faigel DO. Standards of Practice Committee: ASGE Guideline: the role of endoscopy in the management of variceal hemorrhage, updated July 2005. Gastrointest Endosc. 2005;62(5):651-5.

28. Chandok N, Kamath PS, Blei A, Bosch J, Carey W, Grace N, Kowdley KV, Benner K, Groszmann RJ. Randomised Clinical trial: the safety and efficacy of long-acting octreotide in patients with portal hypertension. Aliment Pharmacol Ther. 2012a;35(8):904-12.

29. Garcia-Tsao G, Sanyal AJ, Grace ND, Carey W, Practice Guidelines Committee of the American Association for the Study of Liver Diseases, Practice Parameters Committee of the American College of Gastroenterology. Prevention and management of gastroesophageal varices and variceal hemorrhage in cirrhosis. Hepatology. 2007; 46(3): 922-938.

30. Wells M, Chande N, Adams P, Beaton M, Levstik M, Boyce E, Mrkobrada M. Meta-analysis: vasoactive medications for the management of acute variceal bleeds. Aliment Pharmacol Ther. 2012;35(11):1267-78.

31. Fortune B, Garcia-Tsao G. Current management strategies for acute esophageal variceal hemorrhage. Curr Hepatol Rep. 2014;13(1):35-42.

32. Spahr L, Giostra E, Frossard JL, Morard I, Mentha G, Hadengue A. A 3-month course of long-acting repeatable Octreotide (Sandostatin LAR) improves portal hypertension inpatients with cirrhosis: a randomized controlled study. Am J Gastroenterol. 2007;102:1397-405.

33. US Food and Drug Administration. Guidance for Industry: Bioanalytical Method Validation. US Department of Health and Human Services, Food and Drug Administration, Center for Drug Evaluation and Research: Rockville, MD, 2001. https://www.fda.gov/CVM. Accessed 20 May 2001.

34. Thanou M, Verhoef JC, Marbach P, Junginger HE. Intestinal absorption of octreotide: N-trimethyl chitosan chloride (TMC) ameliorates the permeability and absorption properties of the somatostatin analogue in vitro and in vivo. J Pharm Sci. 2000;89:951-7.

35. Tuvia S, Atsmon J, Teichman SL, Katz S, Salama P, Pelled D, Landau I, Karmeli I, Bidlingmaier M, Strasburger CJ, Kleinberg DL, Melmed S, Mamluk R. Oral octreotide absorption in human subjects: comparable pharmacokinetics to parenteral octreotide and effective growth hormone suppression. J Clin Endocrinol Metab. 2012;97:2363-9.

36. Melmed S, Popovic V, Bidlingmaier M, Mercado $M$, van der Lely AJ, Biermasz N, Bolanowski M, Coculescu M, Schopohl J, Racz K, Glaser B, Goth M, Greenman Y, Trainer P, Mezosi E, Shimon I, Giustina A, Korbonits M, Bronstein MD, Kleinberg D, Teichman S, Gliko-Kabir I, Mamluk R, Haviv A, Strasburger C. Safety and efficacy of oral octreotide in acromegaly: results of a multicenter phase III trial. J Clin Endocrinol Metab. 2015;100:1699-708.

37. Bornschein J, Drozdov I, Malfertheiner P. Octreotide LAR: safety and tolerability issues. Expert Opin Drug Saf. 2009;8(6):755-68.

38. Chan MM, Chan MM, Mengshol JA, Fish DN, Chan ED. Octreotide: a drug often used in the critical care setting but not well understood. Chest. 2013;144(6):1937-45.

39. Chandok N, Kamath PS, Blei A, Bosch J, Carey W, Grace N, Kowdley KV, Benner K, Groszmann RJ. Randomised clinical trial: the safety and efficacy of long-acting octreotide in patients with portal hypertension. Aliment Pharmacol Ther. 2012b;35(8):904-12.

40. Molina Infante J, Pérez Gallardo B, Fernández BM. Update on medical therapy for obscure gastrointestinal hemorrhage. Rev Esp Enferm Dig. 2007;99(8):457-62
41. Gillis JC, Noble S, Goa KL. Octreotide long-acting release(LAR) A review of its pharmacological properties and therapeutic use in the management of acromegaly. Drug. 1997;53:681-99.

42. Fricker G, Nobmann S, Miller DS. Permeability of porcine blood brain barrier to somatostatin analogues. Br J Pharmacol. 2002;135:1308-14.

43. Fang HM, Xu JM, Mei Q, Diao L, Chen ML, Jin J, Xu XH. Involvement of cytochrome P450 3A4 and P-glycoprotein in first-pass intestinal extraction of omeprazole in rabbits. Acta Pharmacol Sin. 2009;30:1566-72.

44. Miao Q, Liu Q, Wang CY, Meng Q, Guo XJ, Peng JY. Inhibitory effect of zinc on the absorption of JBP485 via the gastrointestinal oligopeptide transporter (PEPT1) in rats. Drug Metab Pharmacokinet. 2011;26:494-502.

45. Zhang J, Wang C, Liu Q, Meng Q, Cang J, Sun H, Gao Y, Kaku T, Liu K. Pharmacokinetic interaction between JBP485 and cephalexin in rats. Drug Metab Dispos. 2010;38:930-8.

46. Guo SB, Duan ZJ, Li Q, Sun XY. Effect of heme oxygenase-1 on renal function in rats with liver cirrhosis. World J Gastroenterol. 2011;17:322-8.

47. Drewe J, Fricker G, Vonderscher J, Beglinger C. Enteral absorption of octreotide: absorption enhancement by polyoxyethylene-24-cholesterol ether. $\mathrm{Br}$ J Pharmacol. 1993;108:298-303.

48. Miao Q, Liu Q, Wang C, Meng Q, Guo X, Peng J, Kaku T, Liu K. Inhibitory effect of zinc on the absorption of JBP485 via the gastrointestinal oligopeptide transporter (PEPT1) in rats. Drug Metab Pharmacokinet. 2011;26:494-502.

49. Tavelin S, Gråsjö J, Taipalensuu J, Ocklind G, Artursson P. Applications of epithelial cell culture in studies of drug transport. Methods Mol Biol. 2002;188:233-72

50. Fan J, Liu S, Du Y, Morrison J, Shipman R, Pang KS. Up-regulation of transporters and enzymes by the vitamin D receptor ligands, 1alpha, 25-dihydroxyvitamin D3 and vitamin D analogs, in the Caco-2 cell monolayer. J Pharmacol Exp Ther. 2009;330:389-402.

51. Mohri K, Uesawa Y. Enzymatic activities in the microsomes prepared from rat small intestinal epithelial cells by differential procedures. Pharm Res. 2001;18:1232-6.

52. Remmele W, Stegner HE. Recommendation for uniform definition of an immunoreactive score (IRS) for immunohistochemical estrogen receptor detection (ER-ICA) in breast cancer tissue. Pathologe. 1987;8:138-40.

53. Chen Y, Wang Y, Zhou J, Gao X, Qu D, Liu C. Study on the mechanism of intestinal absorption of epimedins $\mathrm{a}, \mathrm{B}$ and $\mathrm{C}$ in the Caco-2 cell model. Molecules. 2014;19(1):686-98.

54. Visentin M, Stieger B, Merz M, Kullak-Ublick GA. Octreotide inhibits the bilirubin carriers organic anion transporting polypeptides 1B1 and 1B3 and the multidrug resistance-associated protein 2. J Pharmacol Exp Ther. 2015:355(2):145-51.

55. Hayeshi R, Hilgendorf C, Artursson P, Augustijns P, Brodin B, Dehertogh P, Fisher K, Fossati L, Hovenkamp E, Korjamo T, Masungi C, Maubon N, Mols R, Müllertz A, Mönkkönen J, O'Driscoll C, Oppers-Tiemissen HM, Ragnarsson EG, Rooseboom M, Ungell AL. Comparison of drug transporter gene expression and functionality in Caco-2 cells from 10 different laboratories. Eur J Pharm Sci. 2008;35:383-96.

56. Wang JJ, Liao XH, Ye M, Chen Y. In vitro absorption mechanism of strychnine and the transport interaction with liquiritin in Caco-2 cell monolayer model. Acta Pharm Sin. 2010;45:1160-4.

57. Haigou R, Miyazawa M. Metabolism of (+)-Terpinen-4-ol by Cytochrome P450 Enzyme in Human Liver Microsomes. J Oleo Sci. 2012;61:35-43.

58. Toda T, Ohi K, Kudo T, Yoshida T, Ikarashi N, Ito K, Sugiyama K. Antibiotics suppress Cyp3a in the mouse liver by reducing lithocholic acid- producing intestinal flora. Yakugaku Zasshi. 2009;129:601-8.

59. Long AH. Dynamic changes of cholestatic cirrhosis in rats and its significance. Chin J Integr Tradit Western Nephrol. 2006;16:87-9.

60. Medina-Díaz IM, Estrada-Muñiz E, Reyes-Hernández OD, Ramírez P, Vega L, Elizondo G. Arsenite and its metabolites, MMA(III) and DMA(III), modify CYP3A4, PXR and RXR alpha expression in the small intestine of CYP3A4 transgenic mice. Toxicol Appl Pharmacol. 2009;239:162-8.

61. Li L, Sinz M, Zimmermann K, Wang H. An IGF-1R inhibitor induces CYP3A4 expression through a PXR-independent, non-canonical CAR-related mechanism. J Pharmacol Exp Ther. 2012;340:688-97.

62. Christians U, Schmitz V, Haschke M. Functional interactions between P-glycoprotein and CYP3A in drug metabolism. Expert Opin Drug Metab Toxicol. 2005;1:641-54

63. Yan JK, Zhu J, Gu BL, Yan WH, Xiao YT, Zhou KJ, Wen J, Wang Y, Cai W. Soybean Oil-Based Lipid Emulsion Increases Intestinal Permeability of 
Lipopolysaccharide in Caco-2 Cells by Downregulation of P-Glycoprotein via ERK-FOXO 3a Pathway. Cell Physiol Biochem. 2016;39(4):1581-94.

64. He XJ, Wang WR, Zhang Y. Yang Q: The effect of radixin knockdown on the expression and efflux function of MRP2 in SGC-7901 cells. Eur J Pharm Sci. 2012:46:426-34

65. Huang J, Zhao M, Li X, Ma L, Zhang J, Shi J, Li B, Fan W, Zhou Y. The Cytotoxic Effect of the Benzene Metabolite Hydroquinone is Mediated by the Modulation of MDR1 Expression via the NF-KB Signaling Pathway. Cell Physiol Biochem. 2015:37(2):592-602.
66. Tran TP, Kim HG, Choi JH, Na MK, Jeong HG. Reversal of P-glycoproteinmediated multidrug resistance is induced by mollugin in MCF-7/adriamycin cells. Phytomedicine. 2013;20:622-31.

\section{Publisher's Note}

Springer Nature remains neutral with regard to jurisdictional claims in published maps and institutional affiliations.
Ready to submit your research? Choose BMC and benefit from:

- fast, convenient online submission

- thorough peer review by experienced researchers in your field

- rapid publication on acceptance

- support for research data, including large and complex data types

- gold Open Access which fosters wider collaboration and increased citations

- maximum visibility for your research: over $100 \mathrm{M}$ website views per year

At BMC, research is always in progress.

Learn more biomedcentral.com/submissions 